
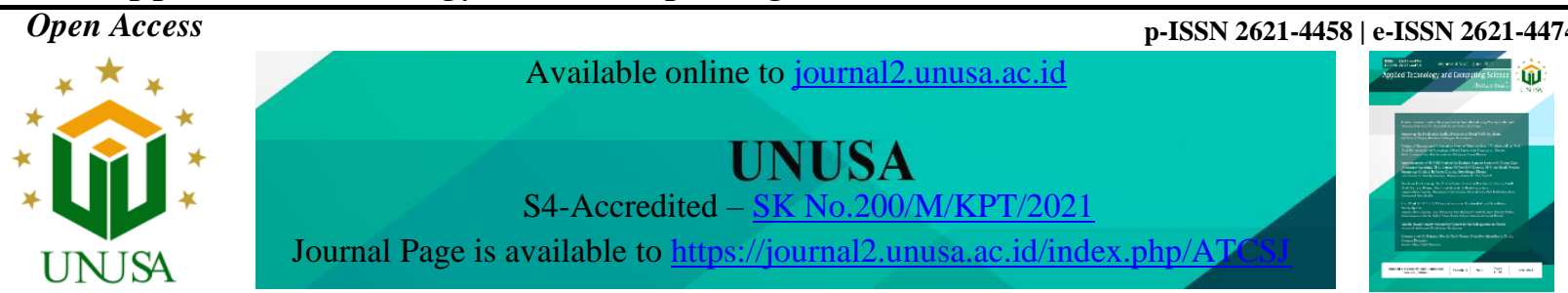

\title{
Use Of ACS 712ELC-5A Current Sensor on Overloaded Load Installation Safety System
}

\author{
Anggara Trisna Nugraha ${ }^{1}$, Alwy Muhammad Ravi², Dadang Priyambodo ${ }^{3}$, Adam \\ Meredita Realdo $^{4}$, Fahmi Ivanuri ${ }^{5}$, Lailia Nur Safitri ${ }^{6}$, Naufal Praska Zakariz ${ }^{7}$, \\ Muhammad Syahid Messiah ${ }^{8}$ \\ 1-8 Marine Electrical Engineering Shipbuilding Institute of Polytechnic Surabaya, Indonesia \\ Jl. Teknik Kimia Keputih Sukolilo, Surabaya \\ 1*anggaranugraha@ppns.ac.id
}

Article history:
Received 9 May 2021
Revised 29 June 2021
Accepted 14 July 2021
Available online 31 July 2021

Keywords:

Microcontroller

Arduino

ACS712

Relay

Sensor

\begin{abstract}
People want energy to satisfy their each day needs. However, maximum of those energy customers are now no longer aware that using an electric powered load is too large, which regularly reasons disturbances. In coping with overload disturbances withinside the family sector, $M C B$ is used as a protection tool. The running precept of the MCB continues to be the usage of magnetic, so it's far less effective. When disconnecting the cutting-edge because of overload, the MCB will experience a touch overdue, which could reason sparks and a hearthplace withinside the family. Therefore, on this look at a cutting-edge sensor protection circuit is designed to update the MCB. This circuit can show the cutting-edge cost at the LCD and restriction the overcurrent to a restriction of three amperes. The overload safety machine constructed from the ACS712ELC-5A cutting-edge sensor can come across currents among $0 A$ and $5 A$. So, to reduce off the cutting-edge, a $12 \mathrm{~V}$ relay is used. When trying out a ready-made machine, this protection tool can study currents withinside the variety $O A$ to $3 A$, with median studying mistakes of $0.65 \%$. If the burden is better than $3 A$, the machine also can reduce the cuttingedge.
\end{abstract}

\section{INTRODUCTION}

Excessive use of hundreds can reason distraction. This extra load will assert the additives via which the present-day flow to heat [1]. One of the additives this is surpassed is a miniature circuit breaker (MCB). This MCB additionally features as a protection overcurrent. However, MCB usually works magnetically so that in the safety process, sparks regularly occur [2]. Because to conquer those shortcomings, a tool for measuring overcurrent and protection is designed and to make specific overloaded protection, and presentday transformers may be used as sensors [3]. In addition to the usage of present-day transformers, overload safety can use semiconductor sensors [4]. ACS 712ELC-5A is a present-day semiconductor sensor [5]. The sensor consists of corridor impact sensors that are capable of discovering fields [6] magnet from the presentday passing via it.

\footnotetext{
${ }^{1 *}$ Corresponding author
} 
The ACS 712ELC-5A sensor may be provided with an electric powered present-day of 5 Ampere [7]. This device will show the weight at the show, and an alarm will include paintings while it's far near the most load [8]. Overload will bring about the disruption of the additives in its path [9]. MCB is one of the additives. This is surpassed with the aid of using an electric-powered present-day earlier than it reaches the weight [10]. MCB features to reduce extra present day, however maximum MCBs paintings magnetically and routinely so that once there may be an extrade in position (transition from ON to OFF and vice versa), sparks will occur [11]. The answer to conquer this hassle is to create a digital-primarily based totally protection system [12]. By enforcing digital primarily based safety measures totally, a couple of sensors are required. Sensors that may be used are consist of semiconductor-primarily based totally or electromagnetic induction-primarily based totally sensors [13]. Ali, Mohamed, in his studies, the usage of the present day of transformer sensors is to examine the present day flowing. However, the sensor reaction used to discover modifications in the present day has a tendency to be slow, particularly $1 \mathrm{~ms}$ [14]. Because to accelerate the response, semiconductor-primarily based sensors totally may be used [15]. In his studies, Slamet Hani, uses a present-day sensor ACS706ELC-20A to examine the present-day flowing in it and bring a voltage of $2.5 \mathrm{VDC}-4.2 \mathrm{VDC}$. With the reference voltage generated with the aid of using the ACS706ELC-20A, it can be used as a present-day proscribing control. This device works primarily based totally at the boom in the electric-powered present-day passing via the ACS706ELC-20A sensor because of the usage of electric powered tools. By putting in a driving force withinside the shape of a BTA41 Triac, the mounted load may be controlled. This device is capable of restricting the usage of the electrical presentday used. In this device, there may be an ACS706ELC-20A sensor which features to examine the presentday used, a seven phase to show the price of the present-day used, and a BTA41 Triac for the weight driving force. However, the sensor has too massive various 20A, so it's far much less particular in measuring smaller currents. According to Febriantoro [3] in his studies, the usage of the ACS712ELC 5\% day sensor is capable of discovering currents with reasonably excessive accuracy, achieving 94.8\%. The sensor reaction to present-day modifications is likewise pretty fast, particularly $5 \mu \mathrm{s}$. With this accuracy, it's far concluded that the usage of the ACS712ELC-5 sensor may be utilized in lighting fixtures set up applications.

\section{METHODS}

The initial stage of this research is to design the hardware (hardware) of the system components used. These components include a current sensor, microcontroller, and indicator display.

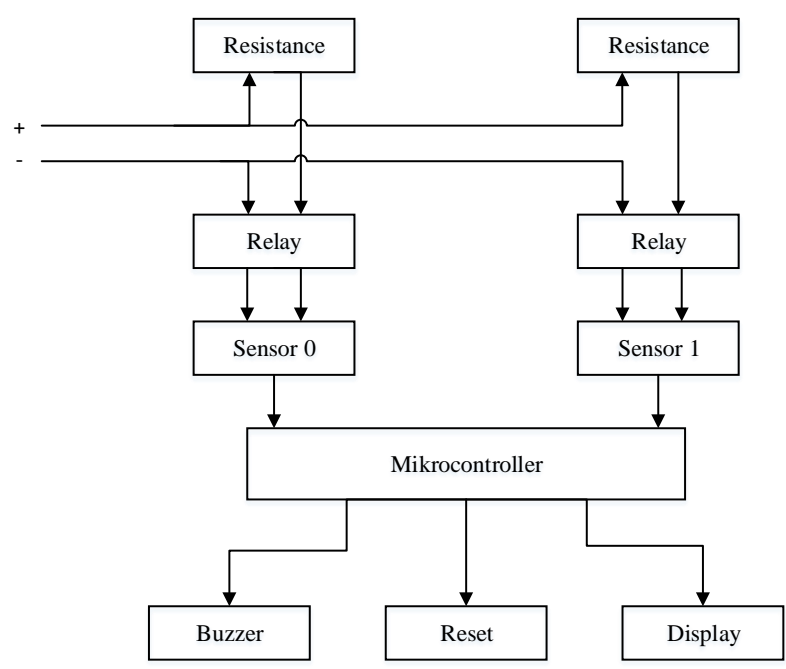

Figure 1. Block Diagram Hardware 
The cutting-edge sensor detects an alternating cutting-edge flowing thru the sensor. The sensor output is withinside the shape of an analog voltage with the intention to be examined through the microcontroller. The ADC converts the analog voltage into virtual voltage, which is then processed at the microcontroller. The LCD screen is used to show the cutting-edge analysis through the advanced sensor. When the cuttingedge exceeds a predetermined limit, the relay acts as a circuit breaker. The buzzer acts as a legitimate or warning and works while the cutting-edge reaches its most advanced.

\section{A. Design software}

The software is made to paintings through analyzing the present-day sensor output voltage continuously. The gadget presents the present-day measured records at the LCD when examining present-day remains under the brink value. When the present-day exceeds the brink value, the microcontroller will prompt the relay to reduce the load's energy. The paintings go with the drift chart or software go with the drift may be visible in Figure 2.

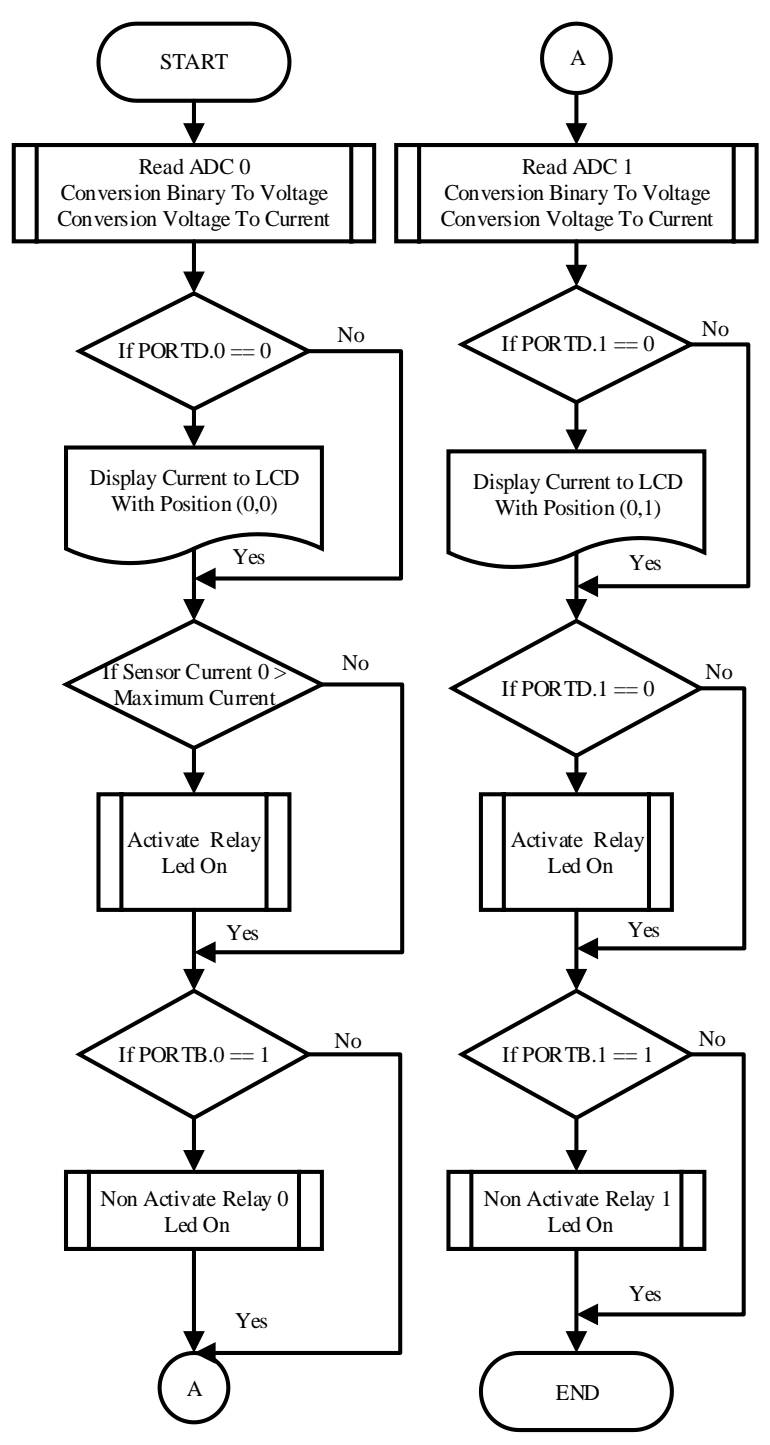

Figure 2. Program flow chart 


\section{B. Atmega16}

In this design, the Atmega sixteen AVR microcontroller is used that is supported with the aid of using numerous components, including a crystal oscillator with a frequency of four Mhz, ceramic capacitors, particularly $22 \mathrm{pF}, 1$ electrolytic capacitor $10 \mathrm{uF}$ and $10 \mathrm{~K} \Omega$, and 1 reset push button.

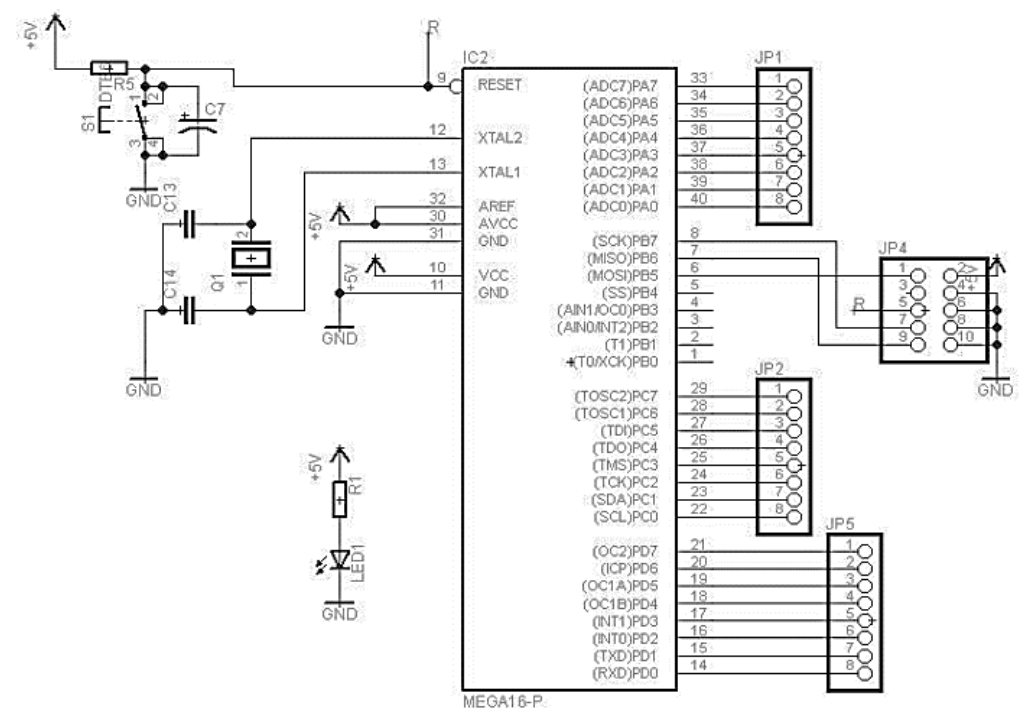

Figure 3. The minimum circuit for the ATMega16 microcontroller system

The microcontroller features used include ADC, input/output ports for buttons, LCD, and indicator LEDs. The ADC used has a 10-bit resolution. Using a reference voltage of 5 volts, you will get an ADC voltage sensitivity of $4.8 \mathrm{mV}$. Calculation of ADC resolution can be seen in equation (1).

$$
\text { res }=\frac{\text { Vref }}{2^{n}}
$$

Where:

RES = ADC Sensitivity (V)

VREF $=$ Reference Voltage $(\mathrm{V})$

$\mathrm{N}=\mathrm{ADC}$ Resolution (BIT)

\section{Current sensor ACS712ELC-5}

The current sensor uses ACS712 type ic and can be used to measure DC or AC currents. This sensor uses the Hall effect principle by detecting a magnetic field generated by a flowing electric current. This sensor has an accuracy of up to $185 \mathrm{mV}$ per Ampere [4]. 


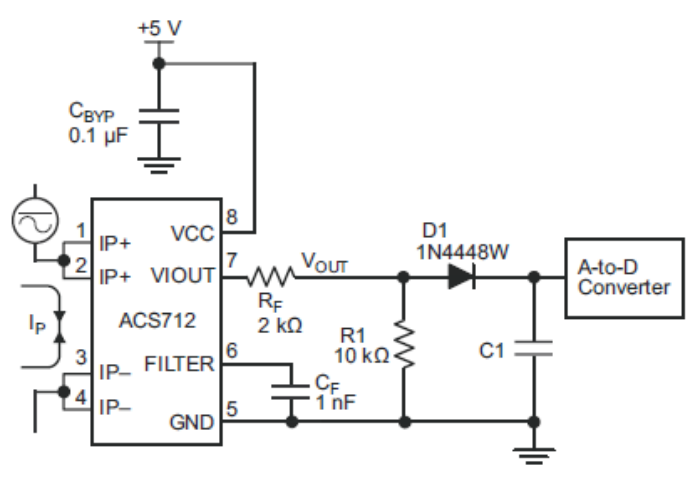

FIGURE 4. Current sensor circuit of ACS712ELC-5

The ACS712 sensor has output voltage pins. The ACS712 output voltage is hooked up to the Out pin, and the voltage is hooked up to an amplifier circuit output. If the amplifier circuit isn't always passed, the equation for buying the output voltage is;

Vout $=2,5 \pm(0,185) . I$

However, via way of means of including an amplifier circuit, a higher sensitivity may be obtained. In this study, a sensor is prepared with an amplifier is used. The output voltage generated via way of means of the sensor is as proven in equation (3).

Vout $=2,5 \pm(0,250) . I$

\section{Display LCD 16x2}

The LCD used to display the current is an alphanumeric LCD with a resolution of $16 x 2$ characters. The LCD used is connected to the microcontroller via PORTC. The LCDs the amount of electric current passing through the sensor.

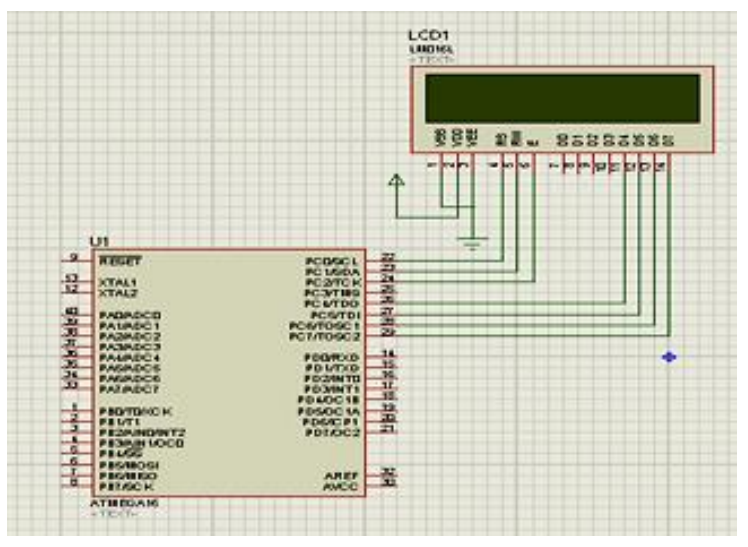

Figure 5. Connection between LCD and microcontroller

\section{E. Relay Circuit}

Due to reduce off the go with the drift of electricity, a relay is used. The relay used is the OMRON MY2J5A kind relay. This relay is a relay with an activation voltage of $12 \mathrm{Vdc}$. The relay is attached to the 
transistor collector pin and the emitter pin related to the ground. When the transistor is induced through the microcontroller, the relay might be active.

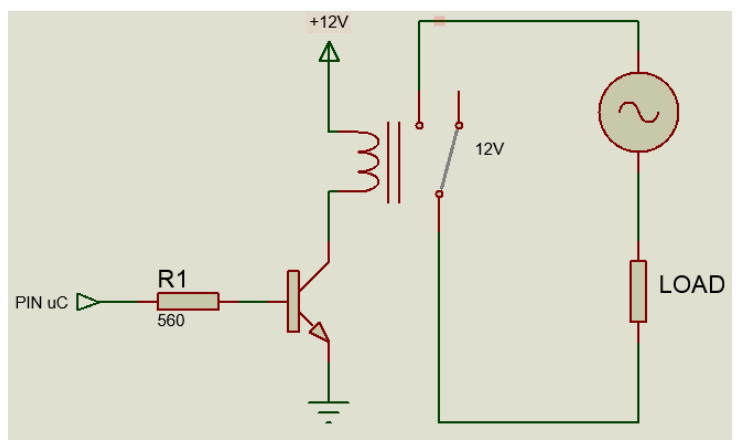

Figure 6. Relay Circuit

All parts are arranged into one system, and the final result can be seen in Figure 7.

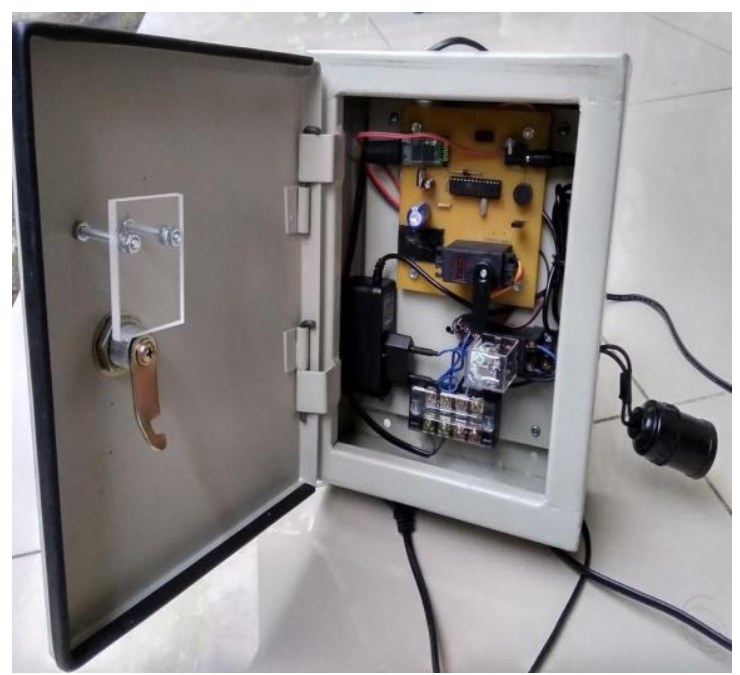

Figure 7. The result of the tool made

\section{RESULT AND DISCUSSIONS}

At this stage, the machine created might be tested. The assessments done encompass checking out the output voltage from the present-day sensor for every present-day flowing, in addition to checking out the whole machine for adjustments in a given load.

\section{A. Current sensor circuit testing}

In this take a look at, a present-day sensor output voltage is measured at every extrude withinside the present-day flowing. The present-day beneath neath take a look at varies from a fee of 0A to 2.4A. Two sensors have been examined. As a comparison, ampere pliers are used to degree the electrical present-day that flows. The first sensor examined issued a voltage of $2.5 \mathrm{~V}$ at no load. As the present-day flows increase, the output voltage additionally increases. At a present-day of $2.4 \mathrm{~A}$, the sensor voltage that comes out is $3.25 \mathrm{~A}$. 
Table 1. Sensor 1 output voltage results to load changes

\begin{tabular}{ccc}
\hline No. & Measured Current & Sensor Output Voltage \\
\hline 1 & $0 \mathrm{~A}$ & $2,5 \mathrm{~V}$ \\
2 & $0,6 \mathrm{~A}$ & $2,65 \mathrm{~V}$ \\
3 & $0,9 \mathrm{~A}$ & $2,75 \mathrm{~V}$ \\
4 & $1,6 \mathrm{~A}$ & $2,85 \mathrm{~V}$ \\
5 & $2 \mathrm{~A}$ & $3 \mathrm{~V}$ \\
6 & $2,4 \mathrm{~A}$ & $3,25 \mathrm{~V}$ \\
\hline
\end{tabular}

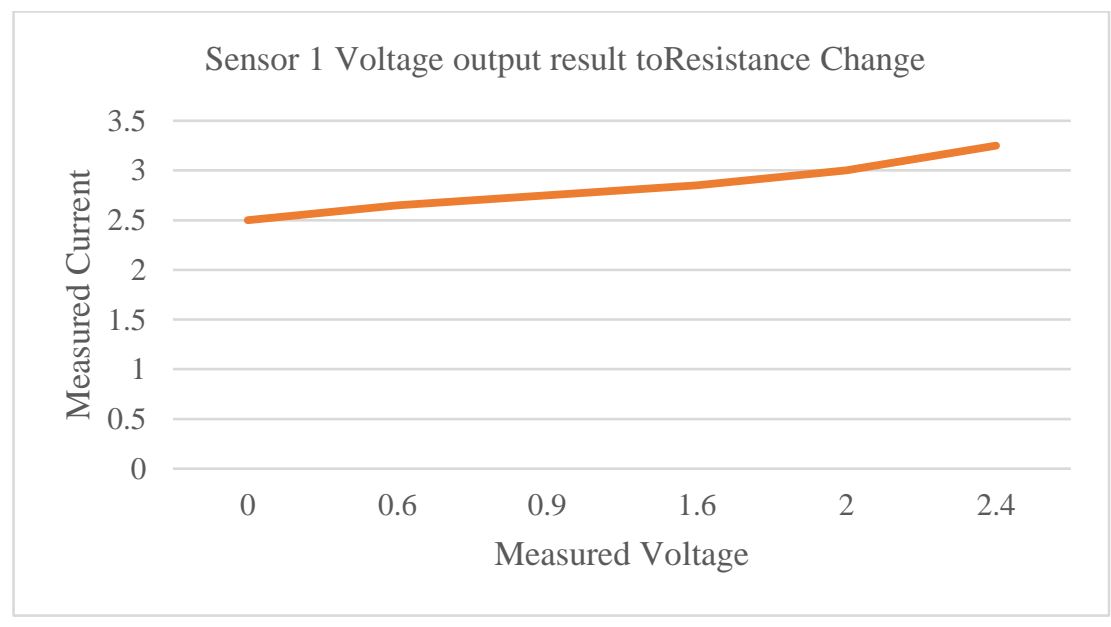

Figure 8. Graph of sensor output voltage 1 results to load changes

The second sensor testing was carried out in the same way. The results can be seen in Table 2 .

Table 2. Sensor 2 output voltage results to load changes

\begin{tabular}{ccc}
\hline No. & Measured Current & Sensor Output Voltage \\
\hline 1 & $0 \mathrm{~A}$ & $2,5 \mathrm{~V}$ \\
2 & $0,5 \mathrm{~A}$ & $2,6 \mathrm{~V}$ \\
3 & $0,8 \mathrm{~A}$ & $2,7 \mathrm{~V}$ \\
4 & $1,5 \mathrm{~A}$ & $2,8 \mathrm{~V}$ \\
5 & $1,9 \mathrm{~A}$ & $2,9 \mathrm{~V}$ \\
6 & $2,3 \mathrm{~A}$ & $3,2 \mathrm{~V}$ \\
\hline
\end{tabular}

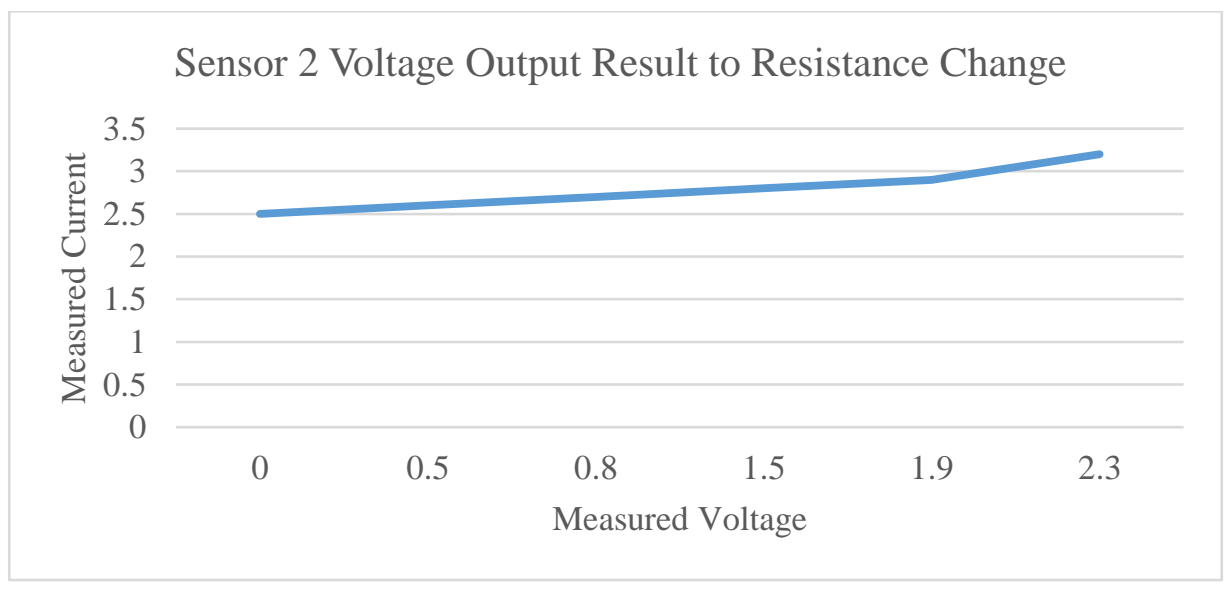

Figure 9. Sensor 2 output voltage results to load changes 
B. System testing for load changes

System trying out for load modifications is completed via supplying load versions, and the consequences are discovered via the LCD. The dimension of electrical modern is compared to the amperage of pliers wherein the distinction in dimension is the cost of the device error. The restrict of the modern this is handed $3 \mathrm{~A}$ in order that the device needs to reduce off the waft of modern if it exceeds this restrict.

Table 3. Results of system testing to load changes

\begin{tabular}{ccccc}
\hline No. & Measured Current & Written Current & Error & Status \\
\hline 1 & $0,682 \mathrm{~A}$ & $0,653 \mathrm{~A}$ & $0.04 \%$ & ON \\
2 & $0,687 \mathrm{~A}$ & $0,528 \mathrm{~A}$ & $0.2 \%$ & ON \\
3 & $0,92 \mathrm{~A}$ & $0,9 \mathrm{~A}$ & $0.2 \%$ & ON \\
4 & $0,949 \mathrm{~A}$ & $0,84 \mathrm{~A}$ & $0.1 \%$ & ON \\
5 & $1,6 \mathrm{~A}$ & $1,672 \mathrm{~A}$ & $0.04 \%$ & ON \\
6 & $1,62 \mathrm{~A}$ & $1,568 \mathrm{~A}$ & $0.03 \%$ & ON \\
7 & $1,94 \mathrm{~A}$ & $1,92 \mathrm{~A}$ & $0.01 \%$ & ON \\
8 & $1,97 \mathrm{~A}$ & $2 \mathrm{~A}$ & $0,01 \%$ & ON \\
9 & $2,23 \mathrm{~A}$ & $2,421 \mathrm{~A}$ & $0,07 \%$ & ON \\
10 & $2,25 \mathrm{~A}$ & $2,358 \mathrm{~A}$ & $0,04 \%$ & ON \\
11 & $3,1 \mathrm{~A}$ & $3,12 \mathrm{~A}$ & $0,01 \%$ & OFF \\
12 & $3,38 \mathrm{~A}$ & $3,34 \mathrm{~A}$ & $0,01 \%$ & OFF \\
\hline \multicolumn{5}{c}{}
\end{tabular}

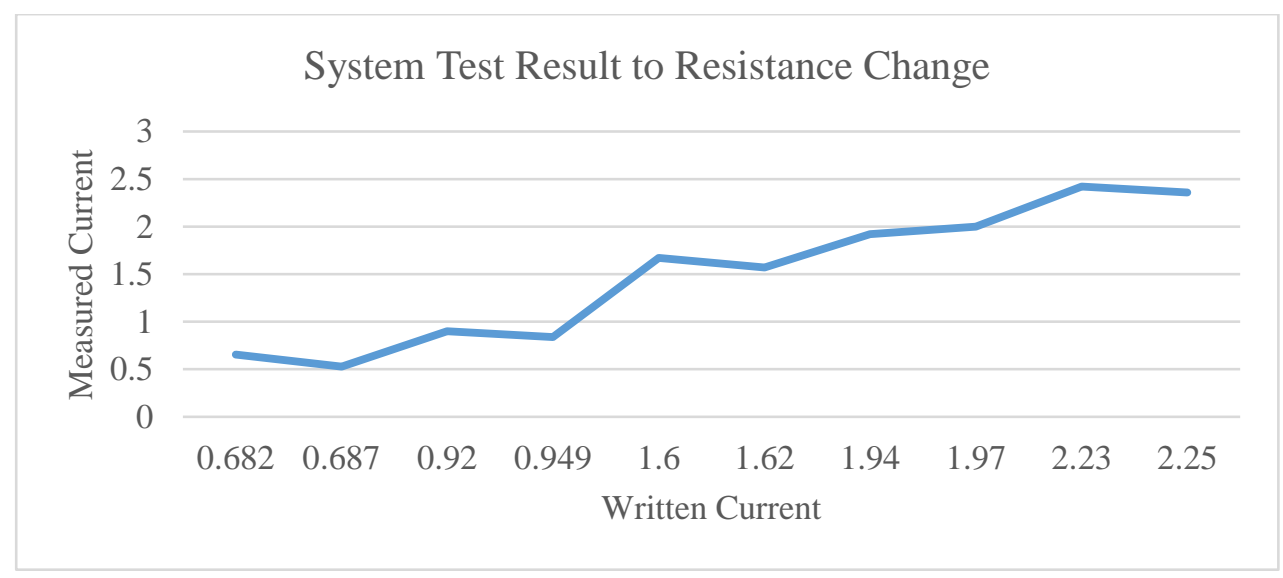

Figure 10. Graph of system test results against changes in load

\section{CONCLUSIONS AND RECOMMENDATIONS}

After conducting experiments and analysis of the tools, it can be concluded that when loading the current sensor is carried out, and there is a difference in the value displayed by sensor 0 with sensor 1 of \pm 0.15 , this is because when setting the reference voltage is done manually. Whereas in the circuit of the ACS 712ELC - 5A Current Sensor, it functions to detect the current passing through it and will be displayed on the LCD, and if the current exceeds the 3 Ampere limit, the relay will cut the current.

\section{REFERENCES}

[1] S. Hani, "Proteksi Arus Lebih Dengan Menggunakan Sensor ACS 706ELC," J. Teknol., vol. 2, no. 2, pp. 167$175,2009$.

[2] M. A. Ali and F. M. Bendary, "Design of prototype non directional overcurrent relay micro-controller-based," 2013.

[3] S. B. C. Febriantoro and B. Suprianto, "Sistem Proteksi Gangguan Arus Lebih Menggunakan Sensor ACS712ELC-5A," J. Pendidik. Tek. Elektro, vol. 3, no. 2, 2014. 
[4] F. Integrated, H. L. Current, and S. Ic, “ACS712.” pp. 1-15, 2020.

[5] R. Galliers and D. E. Leidner, Strategic information management: challenges and strategies in managing information systems. Routledge, 2014.

[6] H. Saadat, Power system analysis, vol. 2. McGraw-hill, 1999.

[7] J. S. Setiadji, T. Machmudsyah, and R. Kongdoro, "Analisa Gangguan Satu Fasa ke Tanah yang Mengakibatkan Sympathetic Trip pada Penyulang yang tidak Terganggu di PLN APJ Surabaya Selatan," J. Tek. Elektro, vol. 6, no. 1, 2006.

[8] S. Ngubel, "Studi penggunaan directional ground relay (DGR) pada penyulang Kebomas gardu induk (GI) Petrokimia, PLN UPJ area Gresik.” Petra Christian University, 2003.

[9] Y. Teguh and Anam Sjamjul, Peralatan Tegangan Tinggi. Institut Teknologi Sepuluh Nopember Surabaya, 1999.

[10] V. Poulek and M. Libra, "A very simple solar tracker for space and terrestrial applications," Sol. Energy Mater. Sol. Cells, vol. 60, no. 2, pp. 99-103, 2000.

[11] A. T. Nugraha and D. Priyambodo, "Design of a Monitoring System for Hydroganics based on Arduino Uno R3 to Realize Sustainable Development Goals number 2 Zero Hunger," J. Electron. Electromed. Eng. Med. Informatics, vol. 3, no. 1, pp. 50-56, 2021.

[12] F. Afifudin and F. S. Hananto, "Optimalisasi Tegangan Keluaran Dari Solar Cell Menggunakan Lensa Pemfokus Cahaya Matahari," J. Neutrino J. Fis. dan Apl., 2012.

[13] E. B. Raharjo, S. Sumardi, and I. Setiawan, "Sistem Kendali Penjejak Sinar Matahari Menggunakan Mikrokontroler ATMEGA8535.” Jurusan Teknik Elektro Fakultas Teknik Undip, 2011.

[14] “ACS712 Module Measures Currents up to 30A for as Low as \$1 Shipped - CNX Software." https://www.cnxsoftware.com/2016/01/23/acs712-module-measures-currents-30a-1-dollar/ (accessed Jul. 31, 2021).

[15] N. Program et al., Microcontroller with $16 \mathrm{~K}$ Bytes In-System Programmable Flash ATmegal6L Preliminary Summary. 